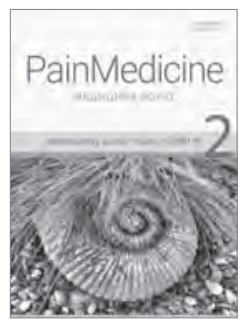

DOI: $10.31636 /$ pmjua.t1.26563

\title{
Реабілітація хворих на хронічний неспецифічний біль у нижній ділянці спини
}

\author{
Бабов К. Д., Косоверов Є. О., Зоярнюк О. С. \\ Український науково-дослідний інститут медичної реабілітації та курортології МОЗ України, \\ м. Одеса, Україна
}

Актуальність. Зростаюча розповсюдженість хронічного неспецифічного болю у нижній ділянці спини (ХНБНДС), а також численна кількість ускладнень, розвиток резистентності при тривалій медикаментозній терапії зумовлює важливість застосування нефармакологічних методів відновлювального лікування у даного контингенту хворих.

Мета дослідження: розробка та вивчення ефективності реабілітаційних комплексів на основі методів фізичної реабілітації та преформованих чинників у відновлювальній терапії хворих на ХНБНДС.

Матеріали і методи дослідження. Під нашим спостереженням перебувало 28 хворих з ХНБНДС. Для об'єктивізації больового синдрому та контролю за ефективністю терапії використано візуальну аналогову шкалу (ВАШ). Інтенсивність больового синдрому у хворих становила $5-7$ балів за даними ВАШ. При обстеженні неврологічного статусу було виявлено ознаки міофасціального больового синдрому (МФСБ). Усім пацієнтам було призначено патогенетично обгрунтований реабілітаційний комплекс із багаторівневим впливом на механізм розвитку хронічного болю: ЛФК з модифікацією рухової активності та методиками, спрямованими на відновлення рухового стереотипу, сполучнотканинний масаж, голкорефлексотерапію, трансорбітальний електрофорез брому, магнітно-лазерну терапію за методиками багаторівневої дії, ультрафонофорез хондропротекторів на поперекову ділянку хребта.

Результати дослідження та їх обговорення. За результатами аналізу, у 21 (73\%) пацієнта інтенсивність больового синдрому за ВАШ зменшилась до 1-2 балів, що відповідало больовому синдрому слабкої інтенсивності. У неврологічному статусі спостерігалася позитивна динаміка в рефлекторній діяльності, зменшення м'язового тонусу, покращення рухової активності.

Висновки. Зважаючи на складність і багаторівневість патогенезу ХНБНДС, сучасний підхід до його лікування полягає в комплексному застосуванні нефармакологічних методів відновлювальної терапії.

Перспективи подальших досліджень. Полягають у розробці, апробації та подальшому впровадженні реабілітаційних комплексів з використанням методів фізичної реабілітації та преформованих фізичних чинників у хворих на ХНБНДС.

Ключові слова: ХНБНДС, багаторівневий реабілітаційний комплекс.

Конфлікт інтересів. Немає. 